\title{
Problems in Appeal System for Students and Its Countermeasures*
}

\author{
Mei Liu \\ Kunming University \\ Kunming, China
}

\begin{abstract}
According to the current situation of appeal system for students in our country, the legal basis of appeal system for students is explored and problems in the present stage are analyzed. Suggestions for improvement of appeal system for students are proposed to safeguard the lawful rights and interests of students.
\end{abstract}

Keywords—students; appeal; rights

\section{INTRODUCTION}

As the constitutional right and democratic right of citizens, right of petition has broad connotation and extension. The right of petition researched here refers to the right of petition on the meaning of procedure instead of democratic politics. It means citizens have the right to complain reasons to competent authorities to anew handle equitably in accordance with legal procedures if citizens are dissatisfied with the treatment on individuals' lawful rights and interests by state organs or other public power organizations and its staff. According to the traditional theory, the right of petition is divided into lawsuit right of petition and non-lawsuit right of petition. The former means in litigious activities, parties involved or other citizens have the right to lodge a complaint to judiciary authorities to handle again if they think the judgment with legal force is wrong; the latter means parties involved or other citizens have the right to directly lodge a complaint to appropriate body without prior judicial proceedings. Students' right of petition belongs to the non-lawsuit right of petition. It means students have the right to complain reasons to education administration organizations or school to handle again in accordance with legal procedures if they think their lawful rights and interests are damaged in receiving education.

\section{LEGAL PRINCIPLE ANALYSIS OF STUDENTS' RIGHT OF PETITION}

According to legal principle analysis, the appeal system for students is the inevitable requirement of using rights to restrict power. In the present organizations of our country, as public institution, schools have dual identity of civil subject and administrative subject according to different legal activities engaged by it. The identity of administrative subject is authorized by accordance with relevant laws and regulations.

*This paper is the phased achievement of scientific planning project of philosophy and social science education of Yunan province in 2015, "Research on Investigation of School Educational Punishment and Legal Principle", project number: AC15012.
The Law of Education of our country stipulates schools have the power of student status management, rewards and punishment for students and degree awarding. The exertion of power has obvious unilateral will and coerciveness and characteristics of administrative power. Public schools are not only social organizations but also authorized organizations to exert national public power in accordance with the authorization of education law or the entrustment of administrative organizations. Law confers administrative power for it to guarantee the smooth implementation of public educational affairs. When schools exert these powers, students and it don't have contractual relation between equal subjects but have special administrative relation.

The idea of "Remedy Precedes Rights" in the theory of modern rule of law also provides legal basis for appeal system of students. "The development of protection mechanism of right doesn't mean the disappearance of infringement. No developed right system can eliminate infringement. The development in protection mechanism of right obstructs the behaviors violating human rights and civic rights on procedure and system, and remedy timely when infringement happens." [1] Appeal system should become the main channel to remedy students' rights. As a legal non-lawsuit remedy system, appeal system has merits like high remedy efficiency, low remedy cost and wide remedy range. Therefore, the appeal system for students is treated as the preceding procedure of litigation relief. Although judicial remedy is neutral, ultimate and authoritative, it has negative factors like long time, complicated procedure, high cost and difficult implementation. According to educational practice, the appearance of lawsuits that students sue alma maters is because of the absent or obstructed complaint channels in schools. Students are compelled to resort to proceedings to safeguard lawful rights and interests of their own. According to judicial practice, because of limited judicial resources and vague theory of administrative proceeding, especially the influence of the theory of special power on public law, some administrative relations especially some internal administrative relations are adjusted by internal system, discipline, professional ethics or policies of organizations. For example, it stipulates in Article 17 of Administrative Procedure Law that administrative organizations shall not take legal actions in appointment and dismissal, rewards and punishments of staff and the people's court shall dismiss these cases. Therefore, the relationship between school and students is regarded as internal administrative relationship excluded from the adjustment range 
of administrative procedure law. In order to establish and improve relief system of students' rights and interests, it is important to establish and improve appeal system for students. The establishment and improvement of appeal system on campus is the priority among priorities.

\section{PROBLEMS IN APPEAL SYSTEM FOR STUDENTS IN OUR COUNTRY}

Students' rights refer to qualifications, interests, ability or propositions of students as the subject of school and education contract, and others including schools have the obligation of not arbitrarily violating and depriving it. It requires in Several Opinions on Strengthening Management of University by Law printed and distributed by the Ministry of Education "establish sound relief channels of rights and interests to guarantee lawful rights and interests of teachers and students according to law and form benign education environment". However, at present, problems in appeal system for students cannot be ignored:

\section{A. The Acceptance Organizations and the Scopes of Appeal for Students Are Unclear.}

In education administrative appeal, laws and regulations of our country stipulate teachers can lodge a complaint to administrative department for education if they think schools or other educational institutions infringe their lawful rights and interests or they are dissatisfied with the treatment; teachers can lodge a complaint to related departments of the people's government at the same level or at the next higher level if they think relevant administrative departments of local people's government infringe their rights stipulated in Teachers Law. No legal provisions exist for students to appeal. It only stipulates students' appeal refers to relevant provisions of teachers' appeal. However, many education administration organizations fail to provide functional organizations and personnel to hear claims. Students and teachers are often accepted by complaint letter and request handling office that deliver the appeal from students and teachers to other administrative offices. Administrative offices mutually make excuses and dismiss. The unsound appeal system inevitably obstructs students to exert the right of petition. Obviously, the educational appeal system of our country has problems like random provision of institutions handling complaints, unclear acceptance departments and absence of due authority and power. It stipulates in Common University Student Management Rule, "the committee handling students' complaints shall consist of head of school, principals of functional departments, teacher representative and student representative". However, no further explanations on the composing proportion, qualifications of members and avoidance principle in the committee handling students' complaints are provided. The committee handling students' complaints has unclear specific responsibilities, unsound institutions, and unreasonable provision of office and absence of personnel guarantee. No appeal system exists for primary and secondary school students. Therefore, corresponding provisions shall be formulated on how to file a complaint, who accept, which can appeal and which cannot appeal, which contents should be included in handling when students appeal when their rights are infringed.

\section{B. The Procedural Norms in Educational Appeal System Are Absent.}

At present, educational laws and regulations in our country lack specific provisions in applicable procedures to handle educational appeal. The operation procedures to handle students' appeal are also unclear. Procedures to handle students' appeal are important in appeal provisions with operability. However, operation procedures and working stages in schools are unclear in actual operation. Students appeal consists of three stages, including application of appeal, acceptance and trial of appeal and handling of appeal. Provisions in appeal system for students don't have clear explanation of the three stages. Currently, many students continue to seek alternative ways of resolution after the treatment of relevant committee of appeal settlement in schools. The reason that cannot be neglected is the absence of systematic and legitimate procedural norms in the procedure of appeal treatment. Students fail to understand and accept the decision in appeal treatment.

\section{The Remedy Approach Is Obstructed after Appealing.}

According to Administrative Provisions for Students, college students can appeal on campus and off campus. Because of the relationship of administrative subordination between colleges and administrative departments for education, the appealing approach is the error correction mechanism within the education system. The existing laws and regulations stipulate the scopes of accepting cases in appeal, reconsideration and lawsuit of college students are different. Some appeal cases can file reconsideration and lawsuit, but clear provisions are absent about how to determine the scope of filing reconsideration and lawsuit and how to link up the three, such as whether students can pursue litigation channel for remedy if related departments fail to handle the appeal from students; whether students can directly file a lawsuit if they are dissatisfied with the handling results of appealing. The Administrative Provisions for Students fails to make the provisions for these problems, leading to the absence and obstruction of remedy approach after appealing. In settlement of administrative legal disputes on campus, the most direct consequence of obstructed administrative litigation approach after educational appeal is that institutions accepting educational administrative appeal, namely education administration organizations at all levels become the most common defendant in administrative litigation. Education administration organizations will become the object of administrative litigation from students and teachers in the next step no matter how they handle appeal cases like maintain, dismiss, reject the complaint or alternate. It weakens the management responsibility of schools. Education administration organizations bear the responsibility of schools. In practice, when administrative legal disputes on campus happen, students and teachers fail to safeguard rights and interests through administrative litigation. Educational appeal becomes the close-ended and final remedy system. 


\section{COUNTERMEASURES TO IMPROVE THE APPEAL SYSTEM FOR STUDENTS}

\section{A. Define the Responsibility of Institutions to Accept Appeal from Students}

The institutions accepting educational appeal and its responsibilities should be explicit to safeguard the right of petition of teachers and students. According to the Administrative Provisions, the committee handling students' appeal consists of principals of relevant functional departments, educational experts and scholars, teacher representative, student representative and lawyers. Except for personnel in charge of educational administration and student management, teacher representatives with equivalent qualification and without additional administrative post should account for more than half (including professionals in pedagogy, psychology and law). Student representatives should be no less than one third. Strict tenure system and regular reelection system in proportion are implemented for members. The appropriate proportion of administrative staff and staff without administrative post should be taken into full consideration in determination of members.

\section{B. Establish the System to Embody the Principle of Disclosure}

It includes announcement system, notification system, and reason-giving system and file system. When handling students' appeal, schools and educational administration departments shall announce provisions of relevant appeal system to students and timely deliver result of handling to person in charge to safeguard students' right to know so that they take necessary remedy measures; all countries give reasons for administrative actions. Similarly, departments must explain reasons to students before performing acts related to students' material rights and interests like deprive or restrict students' rights. On one hand, it ensures "evidence obtaining prior to adjudication" and prevents hypocrisy of public interests. On the other hand, it realizes equal access to information and avoids compulsory acceptance of students. After specific acts, they shall notify students the results; the regulations and decisions related to students' rights, the process, result and evidence of investigation shall be reserved in files and allow related personnel to inquire.

\section{Establish the System to Embod the Principle of Participation}

It mainly refers to the hearing system that enables complainants as interested party to reflect their opinions in decisions of appeal institutions, in order to make power and right countervail. Taking hearing of witnesses as inevitable procedure and the requirement of validity of appeal system safeguards students' right to know, gives students an opportunity to defend themselves and an opportunity for decision-makers to hear all parties. Therefore, hearing system should be included in the appeal system for students. In handling educational disputes, students should be allowed to explain their behaviors and provide evidence. Representatives of students and teachers can participate in the hearing and investigation.

\section{CONCLUSION}

Appeal system, reconsideration system and lawsuit system of education are integration with functional complementation and coordinated development to safeguard students' rights and interests. "Reasonable relation between students' appeal system and lawsuit system should be established to improve students' lawsuit system."[2] Although it is not explicitly stipulated in laws and regulations of our country that students can appeal if they are dissatisfied with the punishment from school, in educational practice, students often turn to judicial channel if the appeal fails to safeguard their rights and interests. The convention of dispute resolution in educational practice indicates it is a tendency that students access to justice if the appeal fails. According to the legal cases happened in schools of our country, the treatments like leaving school, school expulsion and canceling the admission qualification concern students' right to receive education, they often take legal action when appeal fails. Therefore, corresponding cohesive mechanism of appeal system and lawsuit system should be established legally.

\section{REFERENCES}

[1] Xia Yong. Move towards the Time of Rights [M], Beijing: China University of Political Science and Law Press, 1999:8

[2] Yin Xiaomin. Research on Appeal System for College Students [J], Higher Education Exploration, 2004,4 